\title{
Effect of serum factors on the survival of Renibacterium salmoninarum within rainbow trout macrophages
}

\author{
I. Bandín ${ }^{1, *}$, C. Rivas ${ }^{1}$, Y. Santos ${ }^{1}$, C. J. Secombes ${ }^{2}$, J. L. Barja ${ }^{1}$, A. E. Ellis ${ }^{3}$

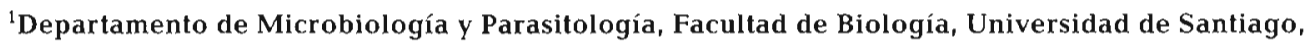 \\ E-15706 Santiago de Compostela, Spain \\ ${ }^{2}$ Department of Zoology, University of Aberdeen, Tillydrone Avenue, Aberdeen AB9 2TN, Scotland, UK \\ ${ }^{3}$ SOAFD, Marine Laboratory, PO Box 101, Victoria Road, Aberdeen AB9 8DB, Scotland, UK
}

\begin{abstract}
While the phagocytosis of Renibacterium salmoninarum by rainbow trout macrophages in vitro occurred in the absence of serum factors, opsonized bacteria once phagocytosed survived for a longer period than bacteria not exposed to serum. Immune sera favoured survival to a greater extent than non-immune sera. Although heat-inactivated immune sera reduced the extent of bacterial killing, bacterial persistence was enhanced to such an extent when both complement and antibodies were present, that opsonized bacteria grew faster within macrophages than extracellularly. The effect of serum was observed following $16 \mathrm{~h}$, but not $3 \mathrm{~h}$, of prior exposure of the bacteria to serum, suggesting that opsonization per se was not the basis for improved survival, but that the serum induced an adaptative change in the bacterium.
\end{abstract}

KEY WORDS: Renibacterium salmoninarum - Rainbow trout - Macrophages S Serum Survival - Killing

\section{INTRODUCTION}

Bacterial kidney disease (BKD) caused by the Grampositive bacterium Renibacterium salmoninarum is a major problem in the culture of salmonids all over the world (Fryer \& Sanders 1981). Circumstantial evidence for the intracellular nature of $R$. salmoninarum infection has long been provided by the histopathology accompanying the disease (Young \& Chapman 1978, Bruno \& Munro 1986). We have previously demonstrated (Bandín et al. 1993) that $R$. salmoninarum can survive in contact with rainbow trout macrophages for up to $4 \mathrm{~d}$, but thereafter killing of the bacterium was observed. At present no information is available concerning the mechanisms that allow the persistence of $R$. salmoninarum within macrophages or the intracellular antimicrobial mechanisms which determine the decline of the pathogen as measured in the in vitro assays.

•E-mail: mpaetjlb@usc.es
Phagocytosis followed by intracellular killing represents an important effector mechanism for eradication of infectious agents. Opsonization is the process of preparation for phagocytosis of microorganisms which are otherwise not recognized or which have developed strategies for preventing their engulfment and is primarily mediated by antibodies and complement (Kaufmann \& Reddehase 1989).

Studies focused on the opsonic effect of fish antibodies and/or complement are not very frequent. However, opsonizing activity of anti-Aeromonas salmonicida and anti-Yersinia ruckeri antibodies has been demonstrated in rainbow trout Oncorhynchus mykiss after the inactivation of complement (Griffin 1983, Sakai 1984, Michel et al. 1991). The involvement of rainbow trout complement in the phagocytosis of $A$. salmonicida and $R$. salmoninarum has also been reported (Sakai 1984, Rose \& Levine 1992).

In most of the cases studied opsonization is to the benefit of the host because potentially infectious agents succumb to intracellular killing. However, some 
pathogens can use the opsonizing process to their own advantage, facilitating their entry into host cells (Moulder 1985, Kaufmann \& Reddehase 1989).

In the present work the effect of normal and immune serum on the phagocytosis of Renibacterium salmoninarum as well as on the induction or avoidance of killing of the phagocytosed bacteria was studied.

\section{MATERIALS AND METHODS}

Bacterial strains. Two virulent autoagglutinating strains of Renibacterium salmoninarum were used in the present study: MT 420 (isolated from Atlantic salmon Salmo salar, Scotland) and RPC1 (coho salmon Oncorhynchus kisutch, Spain). The reference strain ATCC 33209 (American Type Culture Collection, Rockville, MD, USA) was also utilized. The working cultures were maintained on Mueller-Hinton Agar (Difco Laboratories, MI, USA) supplemented with $0.1 \%$ cysteine hydrochloride (MHA-C) at $15^{\circ} \mathrm{C}$ for no more than $7 \mathrm{~d}$ and stored frozen at $-70^{\circ} \mathrm{C}$ in Mueller-Hinton Broth plus cysteine with $15 \%$ v/v glycerol until used.

Fish and immunization procedures. Rainbow trout Oncorhynchus mykiss (200 to $500 \mathrm{~g}$ body weight) were held in tanks supplied with fresh running water at 12 to $15^{\circ} \mathrm{C}$. The fish were anaesthetized with tricaine methanesulfonate (MS 222) during immunization and bleeding procedures.

Formalin-killed Renibacterium salmoninarum ATCC $33209\left(2 \times 10^{9}\right.$ cells $\left.\mathrm{ml}^{-1}\right)$ was emulsified in an equal volume of Freund's complete adjuvant. Fish were inoculated intraperitoneally with $0.5 \mathrm{ml}$ of this emulsion. Twenty days after inoculation a booster injection, identical in composition to the primary injection, was performed and serum was collected after a further $29 \mathrm{~d}$.

Antiserum and complement. Blood of immunized and non-immunized fish was obtained by bleeding from the caudal vein. The blood was allowed to clot at $4^{\circ} \mathrm{C}$ overnight; the serum was removed, divided into aliquots and stored at $-80^{\circ} \mathrm{C}$.

Isolation of trout macrophages. Macrophages were obtained from the pronephros of rainbow trout following the procedure described by Graham et al. (1988). Briefly, the head kidney was removed and disrupted through a $100 \mu \mathrm{m}$ nylon mesh with Leibovitz' medium (L-15, Gibco BRL, Life Technologies Ltd, Paisley, Scotland) containing $2 \%$ inactivated $\left(56^{\circ} \mathrm{C}, 30 \mathrm{~min}\right)$ foetal calf serum (iFCS), 1\% penicillin-streptomycin (P/S, Gibco) and $10 \mathrm{U}$ heparin $\mathrm{ml}^{-1}$ (Sigma Chemical Co., St Louis, MO, USA). This cell suspension was layered onto a 34 to $51 \%$ Percoll gradient. Following centrifugation at $400 \times g$ for $25 \mathrm{~min}$, the band of cells separated at the interface was collected, centrifuged for $5 \mathrm{~min}$ at the same speed and resuspended. The viable cell con- centration was determined by trypan blue exclusion, and $100 \mu \mathrm{I}$ of $2 \times 10^{7}$ cells $\mathrm{ml}^{-1}$ in L-15 medium supplemented with $0.1 \% \mathrm{iFCS}$ and $1 \% \mathrm{P} / \mathrm{S}$ was added to 96 well microtitre plates (A/S Nunc, Roskilde, Denmark). After $3 \mathrm{~h}$ incubation at $18^{\circ} \mathrm{C}$, non-adherent cells were removed by washing with L-15 medium and the remaining monolayers were maintained in $\mathrm{L}-15$ medium, with $5 \%$ iFCS and $1 \% \mathrm{P} / \mathrm{S}$, for 1 to $3 \mathrm{~d}$ before use. The number of adherent macrophages was determined by counting the nuclei released following lysis in $0.1 \mathrm{M}$ citric acid, $1 \%$ Tween 20 and $0.05 \%$ crystal violet as described by Chung \& Secombes (1988).

Agglutination tests. A quantitative agglutination test was performed following the procedure of Roberson (1990) by using microtitre plates with serial 2-fold dilutions of $25 \mu$ aliquots of the antiserum. Cell supensions of each strain $\left(10^{9}\right.$ cells $\left.\mathrm{ml}^{-1}\right)$ were used as antigen. For this assay saline solution $(0.02 \% \mathrm{NaCl})$ was used to avoid autoagglutination observed with phosphatebuffered saline (PBS). The titre was recorded as the reciprocal of the highest dilution of the antiserum which gave positive agglutination after incubation overnight at $15^{\circ} \mathrm{C}$. Bacterial suspensions in saline were used as a control.

Electrophoresis and western blotting analysis. Cell surface extracts of Renibacterium salmoninarum strains were obtained as previously described (Bandín et al. 1992). Briefly, bacteria grown on MHA-C were scraped off the plates with saline solution and centrifuged at $7000 \times g$ for $10 \mathrm{~min}\left(4^{\circ} \mathrm{C}\right)$. The cellular pellets were resuspended in $3 \mathrm{ml}$ of $10 \mathrm{mM}$ Tris [hydroxymethyl] amino-methane (Tris), $\mathrm{pH} 8$ plus $0.3 \% \mathrm{NaCl}$ and disrupted by sonic treatment (Branson sonifier 250). After centrifugation at $10000 \times g$ for 1 min, the supernatant fluids were transferred to another tube and centrifuged again for $60 \mathrm{~min}$ at $20000 \times g\left(4^{\circ} \mathrm{C}\right)$. The resultant pellets were dissolved in distilled water and stored frozen at $-30^{\circ} \mathrm{C}$ until use Sodium dodecyl sulfate polyacrylamide gel electrophoresis (SDS-PAGE) was carried out by the method of Laemmli (1970).

Proteins fractionated by electrophoresis were electroblotted from the gel onto nitrocellulose membranes (Bio-Rad Laboratories, Richmond, CA, USA). After transfer, nitrocellulose membranes were blocked for $1 \mathrm{~h}$ with $3 \%$ gelatin in Tris-buffered saline (TBS) before immunostaining.

Gelatin blocked membranes were washed in TBS plus $0.05 \%$ Tween-20 (TTBS) and then incubated for $1 \mathrm{~h}$ in trout serum (1:40). Membranes were washed again and then incubated for $1 \mathrm{~h}$ in rabbit anti-rainbow trout immunoglobulin (1:1000). After further washing membranes were incubated with goat-anti-rabbit IgGalkaline phosphatase conjugate (Bio-Rad) diluted 1:3000. Bands were visualized by incubating mem- 
branes in $0.1 \mathrm{M}$ carbonate buffer ( $\mathrm{pH}$ 9.8) containing tetrazolium blue $\left(0.3 \mathrm{mg} \mathrm{m}^{-1}\right)$ and 5 -bromo-4-chloro3 -indolyl phosphate $\mathrm{p}$-toluidine salt $\left(0.15 \mathrm{mg} \mathrm{ml}^{-1}\right)$. Finally, blots were rinsed in distilled water for approximately 3 min and air-dried.

Incubation of Renibacterium salmoninarum with fish sera. $R$. salmoninarum in $0.02 \% \mathrm{NaCl}$ were incubated for 3 or $16 \mathrm{~h}$ at $15^{\circ} \mathrm{C}$ with $1: 5$ saline-diluted immune and non-immune sera obtained from rainbow trout. In some experiments complement coexisting with antibodies in the immune sera was heat-inactivated (30 min at $44^{\circ} \mathrm{C}$ ) following the recommendations of Sakai (1984). After the incubation period bacteria were removed by centrifugation $(12000 \times g, 5 \mathrm{~min})$, washed 3 times with saline and adjusted to $5 \times 10^{8}$ bacteria $\mathrm{ml}^{-1}$.

Determination of the internalization of Renibacterium salmoninarum by fluorescence microscopy. To differentiate attached bacteria from internalized bacteria the technique described by Devrets \& Campbell (1991) was used. This procedure relies on the labelling of bacteria with fluorescein isothiocyanate (FITC isomer I, Sigma) and the use of ethidium bromide (EB) as a quenching agent. EB is a dye, excluded by live eukaryotic cells, which fluoresces red-orange and causes FITC-labelled targets to shift from green to red fluorescence (Fattorosi et al. 1989). $R$, salmoninarum cells were harvested and adjusted to an optical density $\left(\mathrm{OD}_{600}\right)$ of 0.6 in $0.1 \mathrm{M} \mathrm{NaHCO}_{3}$. Live bacteria were labelled by the addition of FITC to a final concentration of $0.1 \mathrm{mg} \mathrm{ml} \mathrm{mg}^{-1}$ and incubated at $25^{\circ} \mathrm{C}$ for $60 \mathrm{~min}$. Bacteria were pelleted at $12000 \times g$ for $5 \mathrm{~min}$ and washed free of unbound FITC with saline. According to a plating assay this labelling did not affect the viability of $R$. salmoninarum. It is also known that this treatment does not disturb the bacterial surface (Mundi et al. 1991). Macrophage monolayers were prepared in 24 well plates by adding $1 \mathrm{ml}$ of $2 \times 10^{7}$ cells per well, incubating for $3 \mathrm{~h}$ and washing to remove non-adherent cells. The monolayers in $1 \mathrm{ml}$ of $\mathrm{L}-15$ plus $5 \%$ iFCS were inoculated with $100 \mu \mathrm{l}$ of bacteria at a ratio of 1:10. After centrifugation of the bacteria onto the monolayers for $5 \mathrm{~min}$ at $150 \times \mathrm{g}$, infected cultures were incubated at $16^{\circ} \mathrm{C}$ for $1,3,5$ and $7 \mathrm{~d}$. At the end of each incubation period, infected macrophages were scraped off the wells and both cells and medium transferred to a tube. Then, $100 \mu \mathrm{l}$ aliquots were removed and mixed with $\mathrm{EB}\left(50 \mu \mathrm{g} \mathrm{ml}^{-1}\right.$ final concentration) and a $10 \mu \mathrm{l}$ drop was immediately placed on a glass slide, overlaid with a coverslip, and evaluated by fluorescence microscopy under oil immersion. In all the experiments viability of macrophages was determined by trypan blue exclusion. In preliminary experiments with suspensions of $R$. salmoninarum labelled with FITC, the addition of $\mathrm{EB}$ was shown to produce a colour shift from green to red.
Bactericidal assays. The in vitro assay used was a modification of that reported by Graham et al. (1988) and has been previously described (Bandín et al. 1993). Briefly, wells containing viable macrophages in $100 \mu \mathrm{l}$ L-15 medium plus $5 \%$ iFCS were inoculated with $20 \mu \mathrm{l}$ of serial dilutions of normal or serum-exposed Renibacterium salmoninarum in saline. After centrifugation as described above, the infected cultures were incubated at $16^{\circ} \mathrm{C}$ for $1,3,5$ and $7 \mathrm{~d}$. At the end of each incubation period the supernatants were removed from the wells and the intracellular bacteria released by the addition of $50 \mu$ of cold sterile distilled water. Then $100 \mu \mathrm{l}$ of L-15 with $5 \%$ iFCS was added to each well to support the growth of the surviving bacteria for 6,4 , 2 and $0 \mathrm{~d}$, respectively. In control wells, macrophages were lysed by the addition of $50 \mu$ l distilled water. After 10 min the water was removed and $100 \mu \mathrm{L}-15$ with $5 \%$ iFCS was added followed by $20 \mu \mathrm{l}$ of serial dilutions of $R$. salmoninarum in saline. These wells were incubated for $7 \mathrm{~d}$. After this incubation time, viable bacteria present in the wells were quantified by the addition of $10 \mu \mathrm{l} 3$ [4,5-di-methylthiazoyl-2-yl] 2,5diphenyltetrazolium bromide (MTT, $5 \mathrm{mg} \mathrm{ml}^{-1}$ ) which is reduced in proportion to the amount of viable bacteria present. The optical density was read at $620 \mathrm{~nm}$ 15 min later on a multiscan spectrophotometer (Flow). Experiments were carried out in quadruplicate and repeated 3 times (i.e. cells from 3 fish) for each bacterial strain tested. These data were examined statistically, by a 2-tailed Student's $t$-test. Results are expressed as means of data from 3 fish \pm standard deviations.

\section{RESULTS}

\section{Antibody response of rainbow trout}

The agglutinating titres in the immunized fish were low, ranging from 4 to 32 . However, when SDS-PAGEseparated Renibacterium salmoninarum cellular antigens were immunostained with the antiserum obtained in rainbow trout, antibodies were detected against the major and other cell-surface proteins of the bacterium (Fig. 1).

\section{Double fluorescence microscopy}

The utilization of a double fluorescence microscopy technique allowed identification of attached and internalized bacteria. Live bacteria were labelled with FITC and checked to confirm that the labelling did not affect their viability (data not shown). The mixture of labelled bacteria and macrophages was counterstained with EB to change the fluorescence of extracel- 


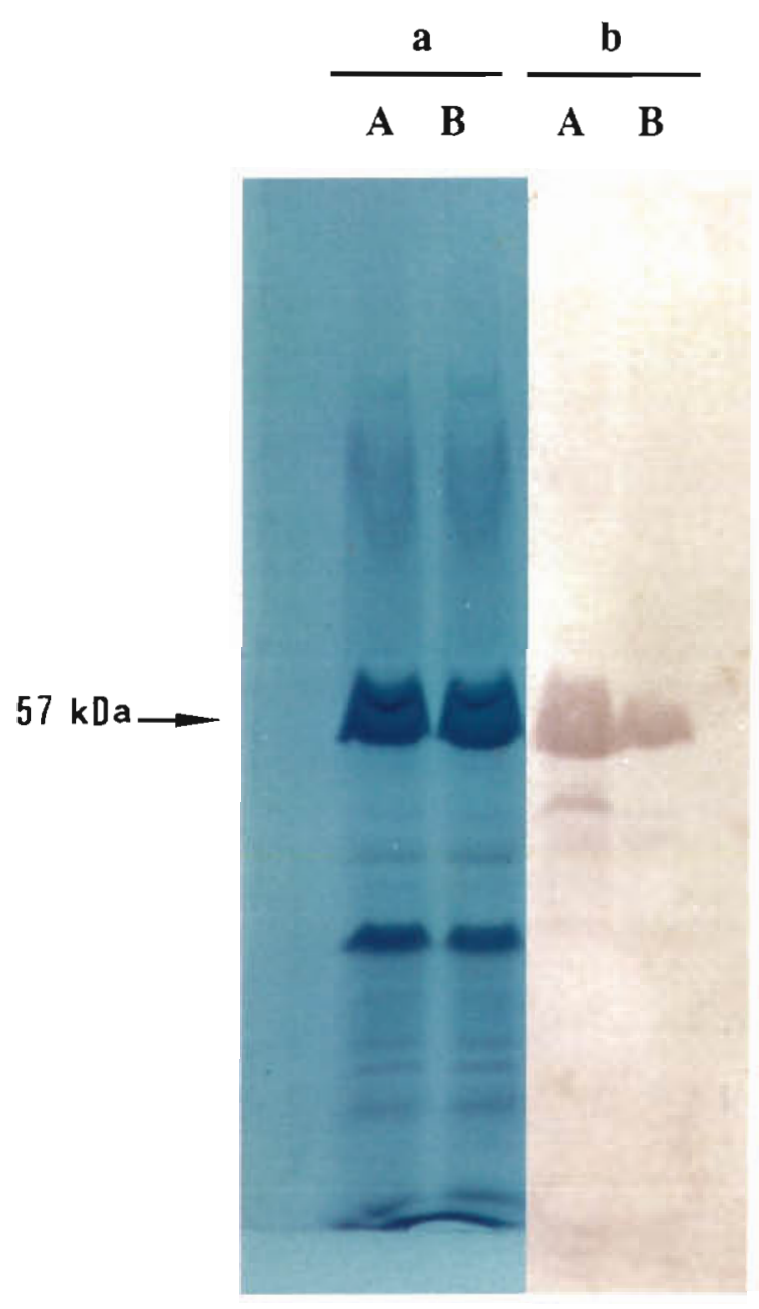

Fig. 1. (a) Renibacterium salmoninarum. SDS-PAGE of membrane proteins from 2 strains. Lane A: ATCC 33209; Lane B: RPC1. (b) Western blot of membrane proteins preparation from $R$. salmoninarum isolates tested with trout serum anti- $R$. salmoninarum ATCC 33209. Lane A: ATCC 33209; Lane B: RPC1

lular bacteria. As a result of the addition of EB, which is excluded by live cells, attached but not internalized bacteria fluoresced red, whereas intracellular Renibacterium salmoninarum fluoresced green. In all the phagocytosis assays after addition of EB more than $85 \%$ of cell-associated bacteria fluoresced green (bacteria from 100 macrophages), indicating that they were internalized and not merely adherent (Fig. 2).

\section{Survival of opsonized Renibacterium salmoninarum within trout macrophages}

The ability of Renibacterium salmoninarum strains opsonized with immune and non-immune rainbow trout serum to survive within macrophages was deter-

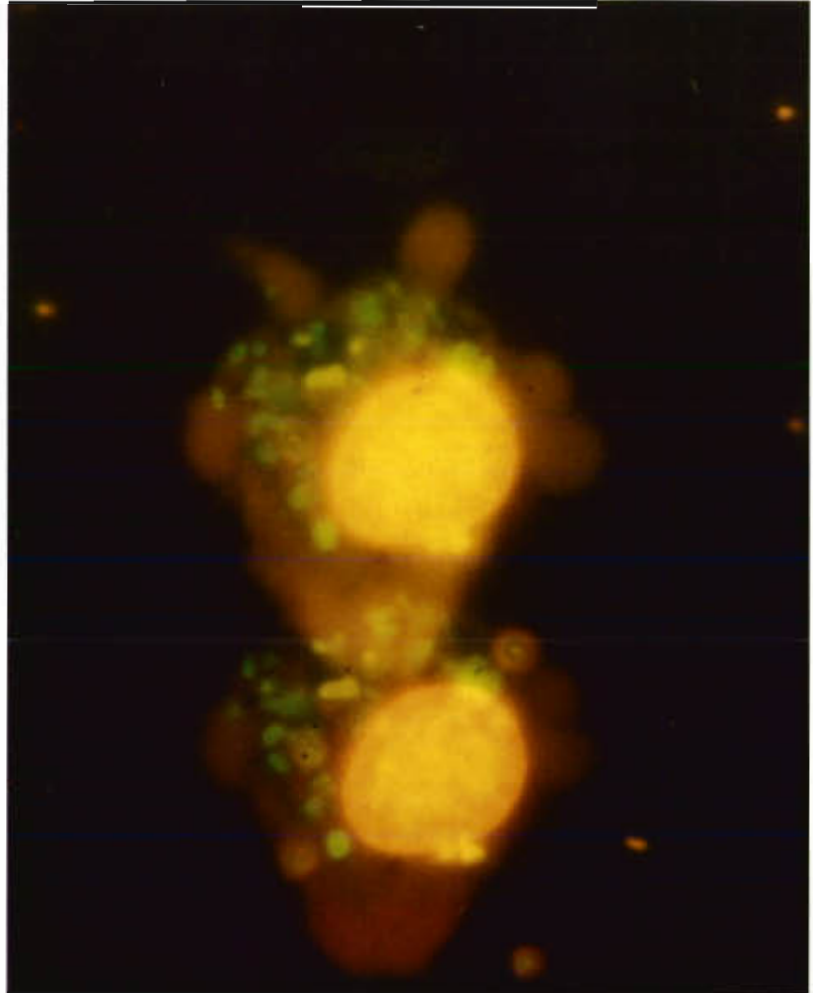

Fig. 2. Fluorescence micrograph of macrophages and phagocytosed FITC-labelled $R$. salmoninarum RPCI with ethidium bromide added. Extracellular bacteria fluoresce red-orange while intracellular bacteria remain green

mined. Identical results were obtained with the 2 strains tested. Figs. 3 \& 4 show the results obtained with strain RPC1.

When the bactericidal assay was performed with bacterial isolates previously incubated with nonimmune sera for $16 \mathrm{~h}$, it was observed that Renibacterium salmoninarum was able to survive up to $5 \mathrm{~d}$ (Fig. 3B), which represents an increase of $1 \mathrm{~d}$ in the bacterial persistence with respect to the killing assays performed with untreated bacteria (Fig. 3A). However, a significant decrease $(p<0.05)$ in the number of viable bacteria was observed at longer incubation times ( 7 d) (Fig. 4B). Figs. 3 \& 4 show the results obtained with RPC1 strain.

When immune serum was employed, Renibacterium salmoninarum strains were able to survive for the $7 \mathrm{~d}$ duration of the assay (Fig. 4C). In addition, it should be pointed out that opsonization with immune serum not only stopped killing, as shown in Fig. 4C, but also slightly increased the growth of intracellular bacteria with respect to the control (bacteria incubated with lysed macrophages). Although the addition of heat-inactivated antiserum (antibody alone) favoured bacterial persistence (data not shown), the survival was notably enhanced when both antibody 

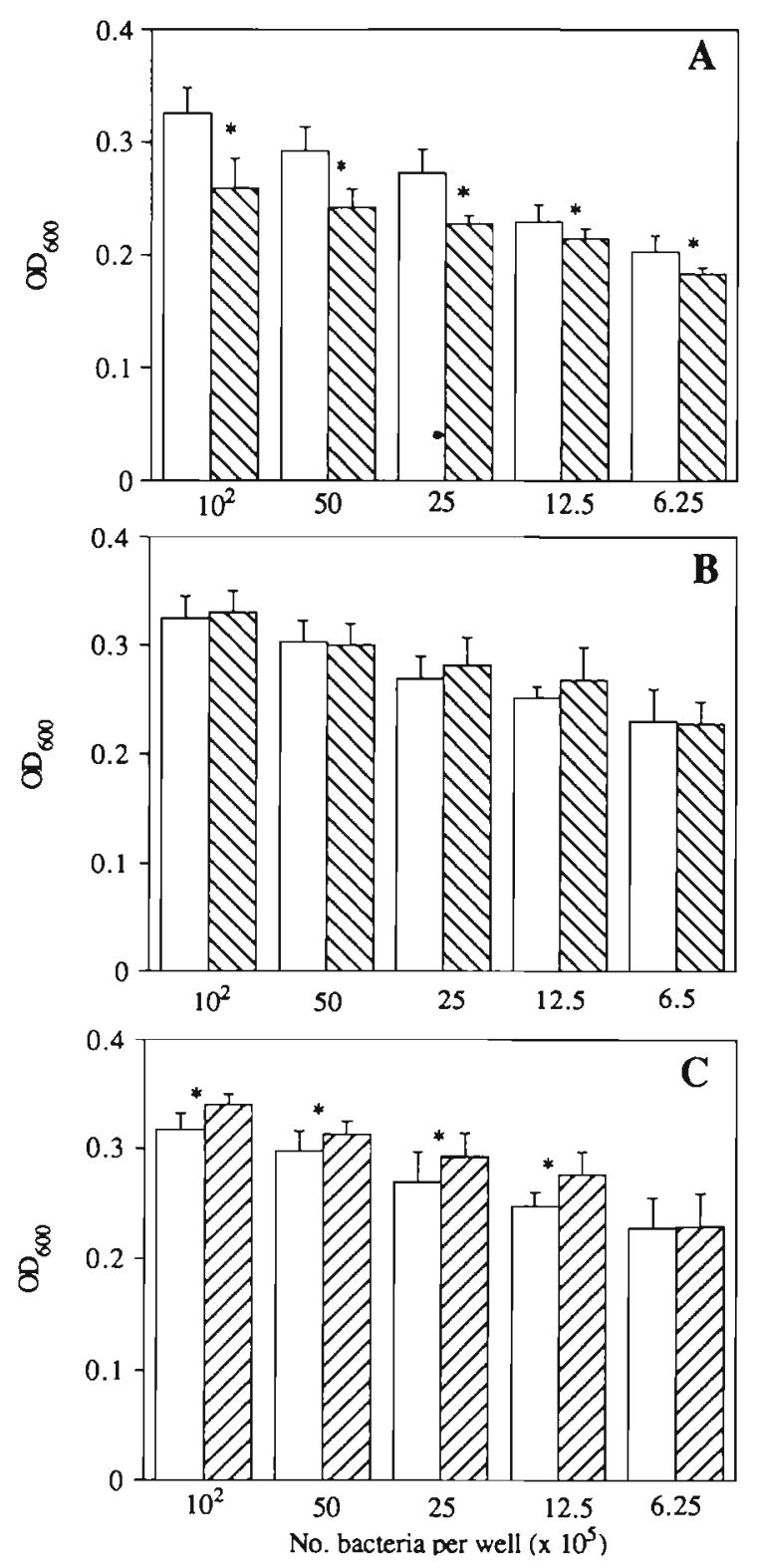

Fig. 3. Infection of rainbow trout macrophages with Renibacterium salmoninarum RPC1 for $5 \mathrm{~d}$. Results are the mean of MTT reduction \pm SD for 3 experiments. ( $\nabla) 5 \mathrm{~d}$ with live macrophages / $2 \mathrm{~d}$ in L-15 plus lysed macrophages; $(\square)$ control, $0 \mathrm{~d}$ with live macrophages $/ 7 \mathrm{~d}$ in L-15 plus lysed macrophages. *Significant differences $(p<0.05)$ between each data point and the control. (A) untreated bacteria; (B) non-immune serum coated bacteria; (C) immune serum coated bacteria

and complement were utilized. No protective effect was observed when bacteria were incubated with the serum for $3 \mathrm{~h}$.

\section{DISCUSSION}

The internalization assay performed with FITClabelled bacteria and EB demonstrated that Renibac-
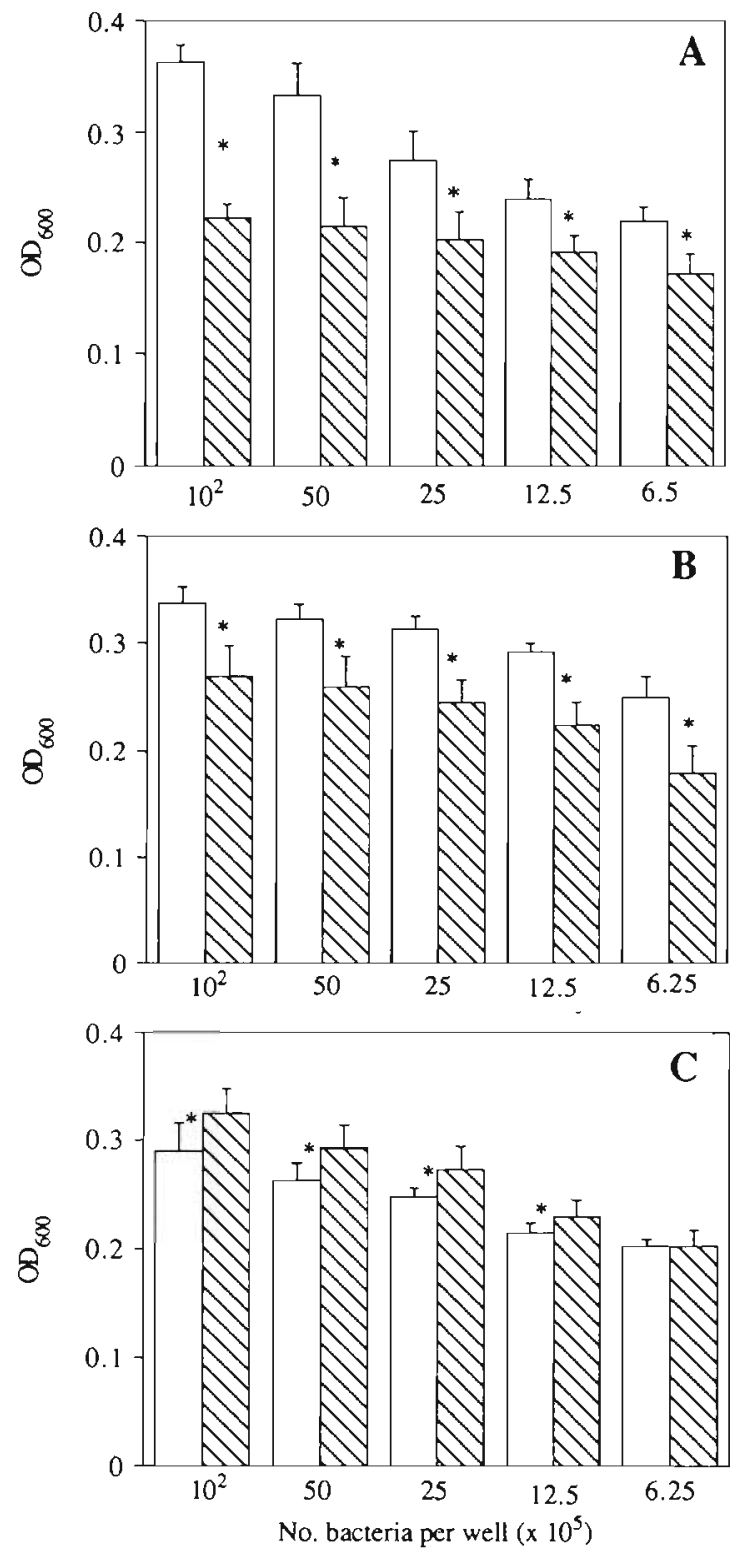

Fig. 4. Infection of rainbow trout macrophages with Renibacterium salmoninarum RPC1 for $5 \mathrm{~d}$. Results are the mean of MTT reduction \pm SD for 3 experiments. $(\Delta) 7 d$ with live macrophages / $0 \mathrm{~d}$ in L-15 plus lysed macrophages; $(\square)$ control, $0 \mathrm{~d}$ with live macrophages $/ 7 \mathrm{~d}$ in L-15 plus lysed macrophages. *Significant differences $(p<0.05)$ between each data point and the control. (A) untreated bacteria; (B) non-immune serum coated bacteria; $(C)$ immune serum coated bacteria

terium salmoninarum is efficiently ingested by trout phagocytes in the absence of serum factors, which is in contrast with results reported by Rose \& Levine (1992). Phagocytosis in the absence of serum suggests a direct cell-bacterium interaction and the hydrophobic surface of $R$. salmoninarum (Daly \& Stevenson 1987. Bruno 1988, Bandín et. al. 1989) may be important in promoting binding of the pathogen to the fish macro- 
phages. In addition, the presence of a high number of internalized bacterial cells $(85 \%)$ at different time points $(1,3,5$ and 7 d) strongly supports the view that $R$. salmoninarum is an intracellular pathogen.

Although our results indicate that serum is not necessary in the phagocytosis of Renibacterium salmoninarum, we did observe differences in the viability of untreated and opsonized bacteria when incubated with trout macrophages. Thus, while untreated bacteria survived for $4 \mathrm{~d}$, bacteria opsonized with nonimmune serum were able to survive for up to $5 \mathrm{~d}$, and the viability was increased up to $7 \mathrm{~d}$ if immune serum was employed. Indeed the data indicated that intracellular growth of the bacteria opsonized with immune serum was enhanced compared with the control (opsonized bacteria incubated with lysed macrophages). These findings seem to indicate that both complement and antibodies would be implicated in the protection of $R$. salmoninarum against the bactericidal activity of trout macrophages.

In mammals the capacity of antibodies of the $\operatorname{IgG}$ class to promote phagocytosis is well established. However, mammalian phagocytes do not bear receptors for IgM on their surface, so IgM itself cannot act as an opsonin (Hiemstra 1992). Although no fish group so far investigated has any Ig class other than IgM, opsonization of bacteria with fish antibodies has been reported to favour phagocytosis (Griffin 1983, Sakai 1984, Michel et aI. 1991)

With the aim of determining the effect of antibodies on the interaction of Renibacterium salmoninarum with the macrophages, complement activity was depleted by heat-inactivating immune serum. The incubation of bacteria with antibodies alone slightly extended bacterial persistence (data not shown). However, it was observed that survival was clearly enhanced when both complement and antibodies were present.

In mammals it has been demonstrated that $\operatorname{Ig} M$ is a very effective activator of the classical pathway of the complement system, so IgM-coated particles can be opsonized with complement components. We hypothesize that although IgM-coated Renibacterium salmoninarum seems to receive a slight protection against the bactericidal activity of macrophages, bacteria could also be opsonized with complement components extending the survival period.

It is interesting to point out that the protective effect of sera was obtained when bacteria were incubated with it for $16 \mathrm{~h}$ but no extension of the survival time was observed with $3 \mathrm{~h}$ of exposure to sera. Bacteria have a remarkable ability to alter their metabolism in response to changing environmental conditions such as temperature, $\mathrm{pH}$, osmolarity and mutrient availability. The bacterial outer membrane is the prime struc- ture through which these adaptations are mediated (Brown \& Williams 1985). It may be possible that incubation of Renibacterium salmoninarum in trout serum for $16 \mathrm{~h}$ but not 3 h resulted in a physiological adaptation of the bacterium to conditions similar to those in vivo which enabled prolonged survival within macrophages.

The complexity of developing a protective anti-BKD vaccine has been assessed by different authors. It has been reported that salmonids seem to be able to produce antibodies against experimental Rexibacterium salmoninarum bacterins, but it has not been clearly shown that the presence of such antibodies confers protection (Paterson et al. 1981, 1985, Munro \& Bruno 1988). In fact, the results obtained in the present work suggest that the presence of antibodies would favour the survival of $R$. salmoninarum within salmonid macrophages and future studies should be focused on the stimulation of a cell-mediated response.

Acknowledgements. I.B. thanks the Universidad de Santiago (Spain) for a research fellowship.

\section{LITERATURE CITED}

Bandin I, Ellis AE, Barja JL, Secombes CJ (1993) Interaction between trout macrophages and Renibacterium salmoninarum in vitro. Fish Shellfish Immunol 3:25-33

Bandín I, Santos Y, Barja JL, Toranzo AE (1989) Influence of the growth conditions on the hydrophobicity of Renibacterium salmoninarum evaluated by different methods. FEMS Microbiol Lett 60:71-78

Bandín I, Santos Y, Maganinos B, Barja JL, Toranzo AE (1992) The detection of two antigenic groups among Renibacterium salmoninarum isolates. FEMS Microbiol Lett 94 : $105-110$

Brown MRW, Williams P (1985) The influence of environment on envelope properties affecting survival of bacteria in infections. Ann Rev Microbiol 39:527-556

Bruno DW (1988) The realtionship between auto-agglutination, cell surface hydrophobicity and virulence of the fish pathogen Renibacterium salmoninarum. FEMS Microbiol Lett 51:135-140

Bruno DW, Munro ALS (1986) Observations on Renibacterium salmoninarum and the salmonid egg. Dis aquat Org 1:83-87

Chung S, Secombes CJ (1988) Analysis of events occurring within teleost macrophages during the respiratory burst. Comp Biochem Physiol 89B:539-544

Daly JG, Stevenson RMW (1987) Hydrophobic and haemagglutinating properties of Renibacterium salmoninarum. J gen Microbiol 133:3575-3580

Devrets DA, Campbell PA (1991) Macrophage phagocytosis: use of fluorescence microscopy to distinguish between extracellular and intracellular bacteria. J Immunol Meth 142:31-38

Fattorosi A, Nisini R, Pizzolo JG, D'Amelio R (1989) New, simple flow cytometry technique to discriminate between internalized and membrane-bound particles in phagocytosis. Cytometry 10:320-325 
Fryer JL, Sanders JE (1981) Bacterial kidney disease of salmonid fish. Ann Rev Microbiol 35:273-298

Graham S, Jeffries AH, Secombes CJ (1988) A novel assay to detect macrophage bactericidal activity in fish: factors influencing the killing of Aeromonas salmonicida. J Fish Dis 11:389-396

Griffin BR (1983) Opsonic effect of rainbow trout (Salmo gairdneri) antibody on phagocytosis of Yersinia rucker by trout leukocytes. Dev comp Immunol 7:253-259

Hiemstra PS (1992) Opsonization. In: Roitt IM, Delves PJ (eds) Encyclopedia of immunology. Academic Press, London, $p$ $1186-1188$

Kaufmann SHE, Reddehase MJ (1989) Infection of phagocytic cells. Curr Opinion Immunol 2:43-49

Laemmli UK (1970) Cleavage of structural protein during the assembly of the head of bacteriophage $T 4$. Nature 227 : $680-685$

Michel C, Dorson M, Faivre B (1991) Opsonizing activity of anti-Aeromonas salmonicida antibodies after inactivation of complement in rainbow trout. Ann Rech Vet 22: $51-58$

Moulder JW (1985) Comparative biology of intracellular parasitism. Microbiol Rev 49:298-337

Mundi H, Björksten B, Swandorg C, Ohman C, Dahlgen C (1991) Extracellular release of reactive oxygen species from human neutrophils upon interaction with Escherichia

Responsible Subject Editor: O. Kinne, Oldendorf/Luhe, Germany coli strains causing renal sacring. Infect Immunol 59: 4168-4172

Munro ALS, Bruno DW (1988) Vaccination against bacterial kidney disease. In: Ellis AE (ed) Fish vaccination. Academic Press, London, p 124-134

Paterson WD. Desautels D, Weber JM (1981) The immune response of Atlantic salmon, Salmo salar L., to the causative agent of bacterial kidney disease, Renibacterium salmoninarum. J Fish Dis 4:99-111

Paterson WD, Lall SP, Airdrie D, Greer P, Greenham G, Poy M (1985) Prevention of disease in salmonids by vaccination and dietary modification. Fish Pathol 20:427-434

Roberson BS (1990) Bacterial agglutination. In: Stolen JS (ed) Techniques in fish immunology. SOS Publications, Fair Haven, NJ, p 81-86

Rose AS, Levine RP (1992) Complement-mediated opsonization and phagocytosis of Renibacterium salmoninarum. Fish Shellfish Immunol 2:223-240

Sakai DK (1984) Opsonization by fish antibody and complement in the immune phagocytosis by peritoneal exudate cells isolated from salmonid fishes. J Fish Dis 7 : $29-38$

Young CL. Chapman GB (1978) Ultrastructural aspects of the causative agent and renal histopathology of bacterial kidney disease in brook trout (Salvelinus fontinalis). J Fish Res Bd Can 35:1234-1248

Manuscript first received: March 2, 1995

Revised version accepted: September 6, 1995 